\title{
Biological treatment of contaminated air with toluene in an airlift reactor
}

\author{
Alberto O. Vergara-Fernández* \\ Escuela de Ingeniería Ambiental \\ Facultad de Ingeniería \\ Universidad Católica de Temuco \\ Manuel Montt 56 \\ Temuco, Chile \\ Tel: 5645205684 \\ Fax: 5645205430 \\ E-mail: avergara@uctemuco.cl \\ Erich F. Quiroz \\ Escuela de Ingeniería Ambiental \\ Facultad de Ingeniería \\ Universidad Católica de Temuco \\ Manuel Montt 56 \\ Temuco, Chile \\ Germán E. Aroca \\ Escuela de Ingeniería Bioquímica \\ Facultad de Ingeniería \\ Universidad Católica de Valparaíso \\ Av. Brasil 2147 \\ Valparaíso, Chile \\ E-mail: garoca@ucv.cl \\ Nelson A. Alarcón Pulido \\ Departamento de Ingeniería Química \\ Facultad de Ingeniería y Ciencias Geológicas \\ Universidad Católica del Norte \\ Avenida Angamos 0610 \\ Antofagasta, Chile \\ E-mail: nalarcon@ucn.cl
}

Financial support: Dirección de Investigación de la Universidad Católica de Temuco.

Keywords: airlift bioreactors, biofiltration, bioscrubbers, toluene.

Present addresses: "Laboratorio de Química Ambiental, Departamento de Prevención de Riesgos y Medio Ambiente, Universidad Tecnológica Metropolitana, Dieciocho 390, Piso 2, Santiago, Chile.

Abbreviations: EC: elimination capacity

RE: removal efficiency

TL: toluene load

VOC: volatile organic compounds

VIC: volatile inorganic compounds

In this work the variation in the toluene elimination capacity of an airlift bioreactor as a function of the toluene inlet load, using compost as the support material for the microorganisms was studied. In order to evaluate the flexibility of the reactor under changing toluene load, the toluene biodegradation was measured for flows from $2.4 \times 10^{-2}$ to $0.132 \mathrm{~m}^{3} \mathrm{~h}^{-1}$, and a concentration range from 1.4 to $0.8 \mathrm{~g} \mathrm{~m}^{-3}$. Results show a $100 \%$ removal efficiency (RE) for minor flows, however, for a flow increase of $\mathbf{4 5 0} \%$ the RE decreased $40 \%$, reflecting the equipments weak flexibility in varying flows. Meanwhile the maximum elimination capacity obtained was $230 \mathrm{~g} \mathrm{~m}^{-3} \mathrm{~h}^{-1}$, for toluene loads of $550 \mathrm{~g} \mathrm{~m}^{-3} \mathrm{~h}^{-1}$, corresponding to a flow of $0.132 \mathrm{~m}^{3} \mathrm{~h}^{-1}$. It was found that a average biomass concentration in suspension of $3700 \mathrm{~g} \mathrm{~m}^{-3}$, reflected EC's of $203 \mathrm{~g} \mathrm{~m}^{-3} \mathrm{~h}^{-1}$.

Volatile organic compounds (VOC'S) are some of the main atmospheric emissions along with particle matter. The most common VOC'S are alcohols, ketones, aliphatic hydrocarbons and aromatic hydrocarbons BTEX (benzene, toluene, ethylbenzene and xylene isomers) being generated

*Corresponding author 


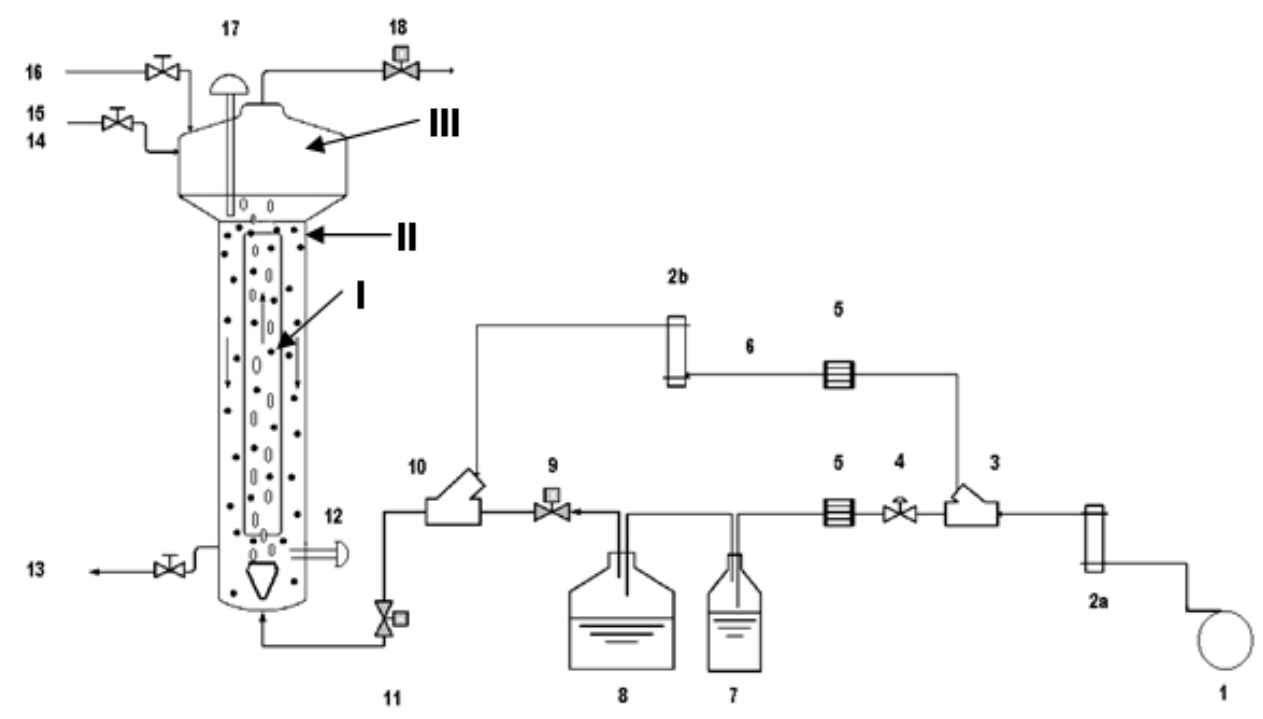

Figure 1. Schematic diagram of the experimental system used. Nomenclature: [1] air compressor; [2a, 2b] flow meters; [3] flow divider; [4] valve; [5] air filter; [6] dilution line; [7] condenser; [8] toluene saturator; [9] gas sample port; [10] mixer; [11] gas sample port; [12] pH electrode; [13] biomass drain; [14] $\mathrm{NaOH}$ supplement; [15] re-circulation of support material; [16] nutrients; [17] thermal dome; [18] gas sample port.

in chemical industries, chemical petroleum's, pasta and adhesive industries, and paint and furniture industries, among others.

A wide range of treatment technologies have been used in the VOC'S and volatile inorganic compounds (VIC's) elimination, being the biofiltration and biotrickling the most utilized biological alternatives (Malhautier et al. 2005; Aroca et al. 2007). Biofiltration is defined as all biological processes used for the control or treatment of VOC'S and inorganic compounds present in the gaseous phase. During the biofiltration process, contaminated air passes through the macropores of the filtered material, degradation of the contaminants takes place before they transfer into air and flow into a liquid film where it is utilized as a carbon and energy source. When biofiltration and biotrickling systems operate for long periods of time, multiple problems can occur (excessive biomass growth, flooding, high pressure drops, preferential flow channels, formation of anaerobic zones and drying of support). These problems can be overcome with the use of airlift bioreactors, when the elimination of water-soluble compounds is desired and when the gas-liquid transport limitation is not a problem (Lo and Hwang, 2004).

Airlift bioreactors are biofilters pertaining to the bioscrubbers group, which are reactors where the existing contaminant in the gaseous phase makes contact with a washing solution (Wubker et al. 1997; Oliveira and de França, 2005). The contaminant is transferred to this solution where it may or may not be biodegraded. In traditional bioscrubbers the biodegradation occurs in an external reactor, whereas in the wash-reaction system it all occurs in the same reactor. The airlift bioreactor corresponds to the latter type, where the biomass is found dispersed in the liquid medium and attached to a support material, also suspended in the liquid phase.

Airlift bioreactors have been extensively used in water treatment; however, its application in gas treatment has been hardly developed (Zuber et al. 1997; Yu et al. 2001). Lo and Hwang (2004) studied gaseous toluene degradation in an airlift bioreactor, obtaining removal efficiency of 50 to $90 \%$. Similar results were obtained by Khandan (1997), for the volatile hydrocarbons elimination, with an operation flow of $1 \mathrm{~L} \mathrm{~min}^{-1}$ in a 3-meter high airlift bioreactor, with temperatures between 20 and $30^{\circ} \mathrm{C}$. However, Khandan (1999) obtained a reduction of 20 to $30 \%$ in the toluene RE in his works with a $10 \mathrm{~L} \mathrm{~min}^{-1}$ flow (an increase of $1000 \%$ ) in a similar reactor.

The objective of the present work was to determine the elimination capacity of the system as a function of the toluene inlet load in a laboratory airlift bioreactor.

\section{MATERIALS AND METHODS}

\section{Microorganisms and support}

Microorganisms correspond to native microbial flora in compost (\% in weight: organic carbon, $20 \%$, total nitrogen, $1.7 \%, \mathrm{P}_{2} \mathrm{O}_{5}, 2.3 \%, \mathrm{~K}_{2} \mathrm{O}, 1.3 \%$ and $\left.\mathrm{Ca}, 5 \%\right)$. The diameter of the support particles was selected by sieving through Tyler standard meshes between 355 and $710 \mathrm{~nm}$ (W.S. TYLER RX-86-3). The compost concentration in the bioreactor was $20 \mathrm{~g} \mathrm{~L}^{-1}$, according to Tijhuis et al. (1995). For the inoculation preparation of the airlift bioreactor, $200 \mathrm{~mL}$ of 


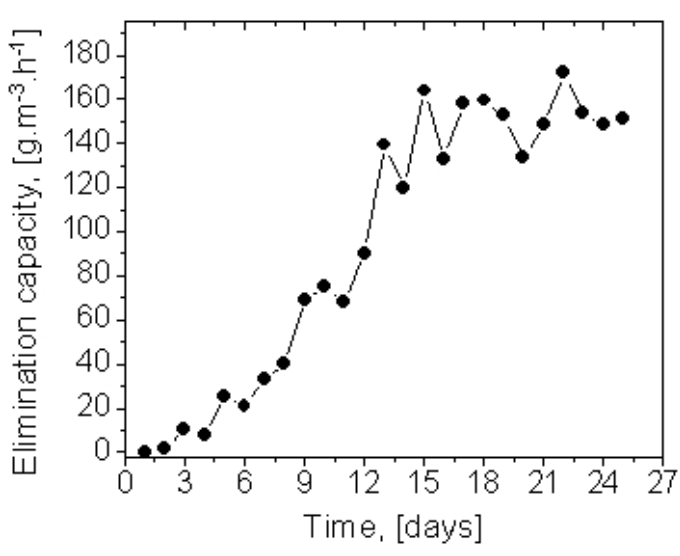

Figure 2. Evolution of the toluene EC in the airlift bioreactor with a toluene inlet load of $160\left(\mathrm{~g} \mathrm{~m}^{-3} \mathrm{~h}^{-1}\right)$.

the cultivation medium was prepared. To this solution was added $5 \mathrm{~g}$ of compost and $10 \mathrm{~g}$ sludge of wastewater treatment. The material was then incubated in a Thermo Forma incubating shaker, model 420, at $220 \mathrm{rpm}$ and $37^{\circ} \mathrm{C}$, for 15 days (Vergara-Fernández et al. 2007). A periodic purge in the bioreactor was done to control the biomass concentration between 2500 and $8000 \mathrm{~g} \mathrm{~m}^{-3}$.

\section{Mineral medium and carbon source}

The mineral medium used for maintenance, growth and biofiltration experiments was $\left(\mathrm{NH}_{4}\right)_{2} \mathrm{SO}_{4}$ : $1.14\left(\mathrm{~g} \mathrm{~L}^{-1}\right)$, $\mathrm{KH}_{2} \mathrm{PO}_{4}: \quad 0.22\left(\mathrm{~g} \mathrm{~L}^{-1}\right), \quad \mathrm{FeSO}_{4} \cdot 7 \mathrm{H}_{2} \mathrm{O}: 0.092 \quad\left(\mathrm{~g} \mathrm{~L}^{-1}\right)$ (Khandan, 1999). The model compound utilized as a carbon and energy source was liquid toluene (Fisher, 99,9\%).

\section{Bioreactor}

The reactor utilized corresponds to an airlift bioreactor with a total volume of $3.1 \mathrm{~L}$, with a useful volume of $2 \mathrm{~L}$, divided into three zones, as Figure 1 shows: (l) Airing of rising fluid, (ll) descending fluid and (lll) liquid-gas separation zone located at the bioreactor limit, with a volume of $1.1 \mathrm{~L}$.

The air is fed into the system by a THOMAS TA-3101 compressor [1] at a controlled pressure between 20-30 psi. The total entry flow into the system is measured with a Cole-Parmer N082-03 rotameter [2a].

The total feed flow is divided into two streams [3]. One of these is deviated towards an air filter [5], and the flow continues towards the toluene saturation system, which consists of a Pyrex recipient [8], total volume $500 \mathrm{~mL}$, containing $200 \mathrm{~mL}$ liquid toluene. In this stage, the air coming from the compressor enters a $500 \mathrm{~mL}$ condenser [7], before the saturator, to collect the water and prevent it from entering the toluene saturator. Here, the liquid toluene is kept at $3^{\circ} \mathrm{C}$ using an ice-based refrigeration system, and its vapors are picked up by the air stream. The second air stream is the dilution line [6] and is measured by a ColeParmer N012-10 rotameter [2b]. The two streams are mixed using a glass mixer [10].

Previous to initiating determination of the toluene load effect in the operation of the bioreactor, it was operated for 25 days to parameter adjustment and acclimatization of the microbial flora, until reaching the stationary state of the system, using a toluene inlet load of $160 \mathrm{~g} \mathrm{~m}^{-3} \mathrm{~h}^{-1}$. Then, the biofilter experiment with gas flow between $2.4 \times 10^{-2}$ and $0.132 \mathrm{~m}^{3} \mathrm{~h}^{-1}$ was initiated, corresponding to residence time between 0.18 and $1.1 \mathrm{~min}$, respectively. To evaluate the influence of toluene inlet load in the elimination capacity of the biofilter, different concentrations of toluene between 8 and $14 \mathrm{~g} \mathrm{~m}^{-3}$ were tested (toluene inlet load between 160 and $550 \mathrm{~g} \mathrm{~m}^{-3} \mathrm{~h}^{-1}$ ), maintaining a constant gas flow rate.

The results for the reactor experiments were expressed in terms of the toluene inlet load (TL, $\mathrm{g} \mathrm{m}^{-3} \mathrm{~h}^{-1}$ ), gaseous toluene elimination capacity (EC, $\mathrm{g} \mathrm{m}^{-3} \mathrm{~h}^{-1}$ ) and removal efficiency (\%RE) according to the following equations.

$$
\begin{aligned}
& \mathrm{TL}=\frac{\mathrm{Q}}{\mathrm{V}_{\mathrm{r}}} \mathrm{C}_{\mathrm{go}} \\
& \mathrm{EC}=\frac{\mathrm{Q}}{\mathrm{V}_{\mathrm{r}}}\left(\mathrm{C}_{\mathrm{go}}-\mathrm{C}_{\mathrm{gs}}\right)
\end{aligned}
$$

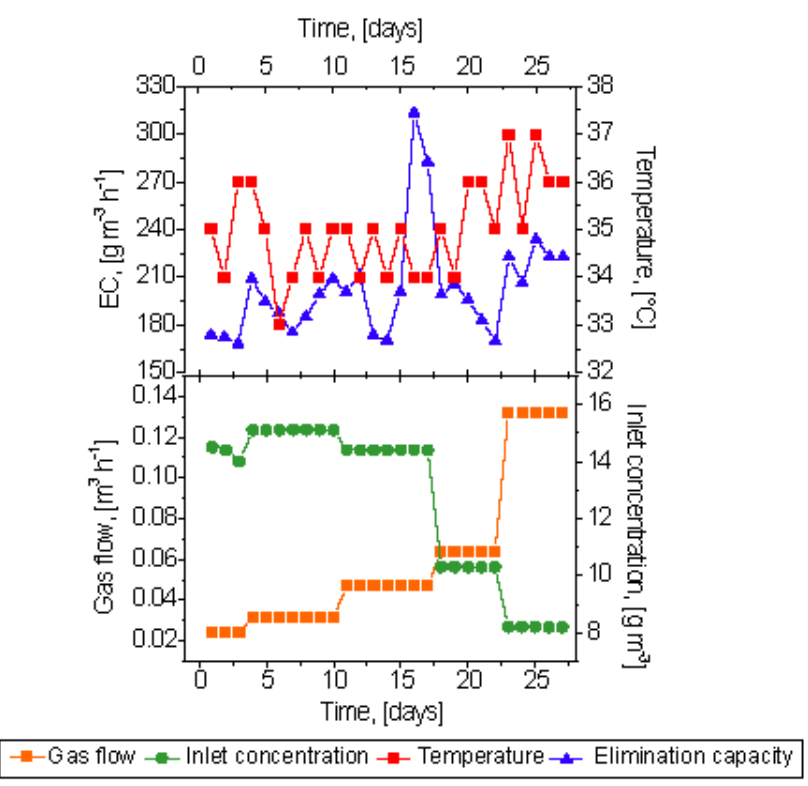

Figure 3. Evolution of elimination capacity in time and its relation to the change in temperature of the reactor, to different flows and work concentrations. 
$\% R E=\frac{C_{g o}-C_{g s}}{C_{g o}} \times 100$

Where, $\mathrm{C}_{\mathrm{go}}$ and $\mathrm{C}_{\mathrm{gs}}$ are the toluene inlet and exit concentrations, respectively $\left(\mathrm{g} \mathrm{m}^{-3}\right), \mathrm{Q}$ is the air flow $\left(\mathrm{m}^{3}\right.$ $\mathrm{h}^{-1}$ ) and $\mathrm{V}_{\mathrm{r}}$ is the useful volume of the bioreactor.

\section{Analytic methods}

To determine the concentration of toluene a Varian gas chromatograph was used, model $3400 \mathrm{CX}$, equipped with a flame ionization detector (detection temperature $250^{\circ} \mathrm{C}$, injection temperature $210^{\circ} \mathrm{C}$, column temperature $140^{\circ} \mathrm{C}$ ), and a capillary column, model SPB-1 (diameter $320 \mathrm{~mm}$; length $30 \mathrm{~m}$, toluene retention time $0.98 \mathrm{~min}$ ), using nitrogen as a carrier gas. The area of the chromatograms was determined using the Star Chromatography Software, version 4.0. A $500 \mathrm{~mL}$ glass bulb was connected to the outflow for taking gas samples. The sample was extracted from the bulb and injected into the chromatograph using a SGE gas syringe, model P/N 008775. The volume of gas injected into the chromatograph was $3 \mathrm{~mL}$.

The $\mathrm{pH}$ was measured using an Orion 1250-A electrode connected to a Hanna Instruments HI 1230 measurer and was kept under control between 6.5 and 7.5 with a solution of $\mathrm{NaOH}(1 \mathrm{M})$ and $\mathrm{HCI}(1 \mathrm{M})$. The bioreactor temperature was kept under control at $35 \pm 2^{\circ} \mathrm{C}$, by means of a thermalregulated chamber. The suspended biomass was determined, prior to sedimentation of the support material, by a dry weight of $105^{\circ} \mathrm{C}$ during 24 hrs.

\section{RESULTS AND DISCUSSION}

\section{Effect on elimination capacity}

Figure 2 shows the start-up results in the airlift bioreactor. In this Figure 2 is observed that stationary state was reached in 27 days, with an elimination capacity of $170 \mathrm{~g}$ $\mathrm{m}^{-3} \mathrm{~h}^{-1}$. In this moment the study of toluene inlet load effect on elimination capacity was initiated.

Figure 3 shows the evolution of the bioreactor EC over time and how it is affected by changes in temperature, flow and toluene concentrations. Figure 3 shows that for gas flows of $3.2 \times 10^{-2} \mathrm{~m}^{3} \mathrm{~h}^{-1}$ with a toluene concentration of $14 \mathrm{~g} \mathrm{~m}^{-3}$, during measuring days 4 and 10, there exists a slight reduction of the EC from 210 to $170 \mathrm{~g} \mathrm{~m}^{-3} \mathrm{~h}^{-1}$, which coincides with the reactor temperature reduction from 36 to $33^{\circ} \mathrm{C}$. Beginning on day 7 , the temperature remained steady between 34 and $35^{\circ} \mathrm{C}$, with the EC recovering on day 10 up to $210 \mathrm{~g} \mathrm{~m}^{-3} \mathrm{~h}^{-1}$. Shortly after day 10 , gas flow increased to $4.74 \times 10^{-2} \mathrm{~m}^{3} \mathrm{~h}^{-1}$, with a $14 \mathrm{~g} \mathrm{~m}^{-3}$ in toluene concentration. The EC remained steady at approximately $190 \mathrm{~g} \mathrm{~m}^{-3} \mathrm{~h}^{-1}$. The existing relationship between the temperature and the toluene EC was also informed by Delhomenie et al. (2003) finding maximum EC of $120 \mathrm{~g} \mathrm{~m}^{-3} \mathrm{~h}^{-1}$ at temperatures of $30^{\circ} \mathrm{C}$ in a drained bed which were $40 \%$ lower than the EC average of $\left(203 \mathrm{~g} \mathrm{~m}^{-3} \mathrm{~h}^{-1}\right)$ obtained to $35 \pm 2^{\circ} \mathrm{C}$ in this work.

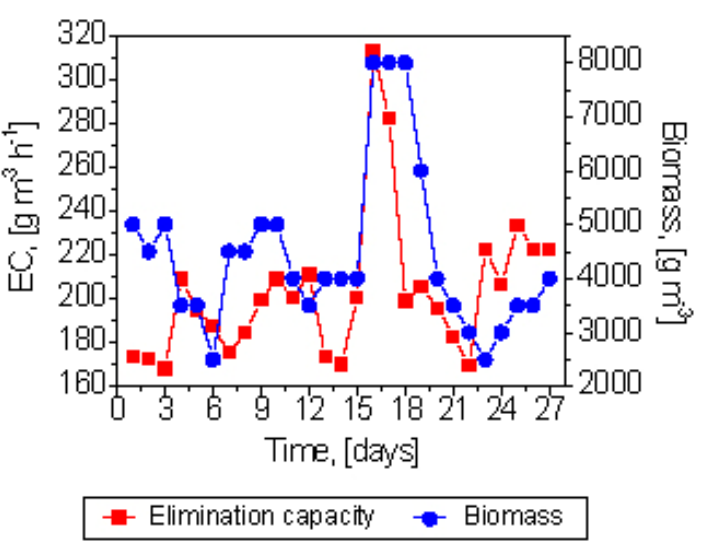

Figure 4. Variation of elimination capacity and suspended biomass in an airlift bioreactor.

On day 16, the EC reached a maximum of $310 \mathrm{~g} \mathrm{~m}^{-3} \mathrm{~h}^{-1}$, which is associated to the increase of biomass concentration, as can be observed in Figure 4. This increase in the biomass concentration creates a greater bioavailability of toluene. The increase in bioavailability of toluene is generated by reducing the partition coefficient in the liquid phase (greater solubility), produced by the presence of proteins, lipoproteins and the same biomass that is generated, generating a change in medium hydrophobicity, according to Vergara-Fernández et al. (2006) and Davison et al. (2000). This suggests that it is possible to eliminate greater quantities of toluene by increasing the concentration of suspended biomass in the reactor. Under these working conditions, the mass transport limitation is reduced and the reaction limitation takes on greater importance.

Subsequently, the EC is again reduced beginning day 17, which coincides with the increase in gas flow of $6.4 \times 10^{-2}$ $\mathrm{m}^{3} \mathrm{~h}^{-1}$, with a toluene concentration of $10 \mathrm{~g} \mathrm{~m}^{-3}$. Finally, gas flow was increased up to $0.132 \mathrm{~m}^{3} \mathrm{~h}^{-1}$, with a toluene concentration of $8 \mathrm{~g} \mathrm{~m}^{-3}$, with the EC steady between 170 and $230 \mathrm{~g} \mathrm{~m}^{-3} \mathrm{~h}^{-1}$.

The average EC obtained (203 $\mathrm{g} \mathrm{m}^{-3} \mathrm{~h}^{-1}$ ) was $25 \%$ greater than that which was obtained by García-Peña et al. (2001) utilizing a biofilter inoculated with the fungus Scedosporium apiospermun TB1 once stationary state was attained. However, this was $23 \%$ lower than the $250 \mathrm{~g} \mathrm{~m}^{-3}$ $\mathrm{h}^{-1}$ attained by Aizpuru et al. (2005) utilizing a fungi biofilter with ceramic rings as support.

From Figure 3, it can be observed that the EC remains relatively constant, under different changes, due to the fact that the contribution to the larger EC produced by an increase in flow will equip itself with the reduction of the concentrated gradient, be it by the reduction of $\mathrm{C}_{\mathrm{go}}$ (due to the reduction in time of contact in the saturator) and/or because $\mathrm{C}_{\mathrm{gs}}$ increases if a good RE is not attained. On the other hand, small $\mathrm{C}_{\mathrm{go}}$ implies less mass transfer velocity 


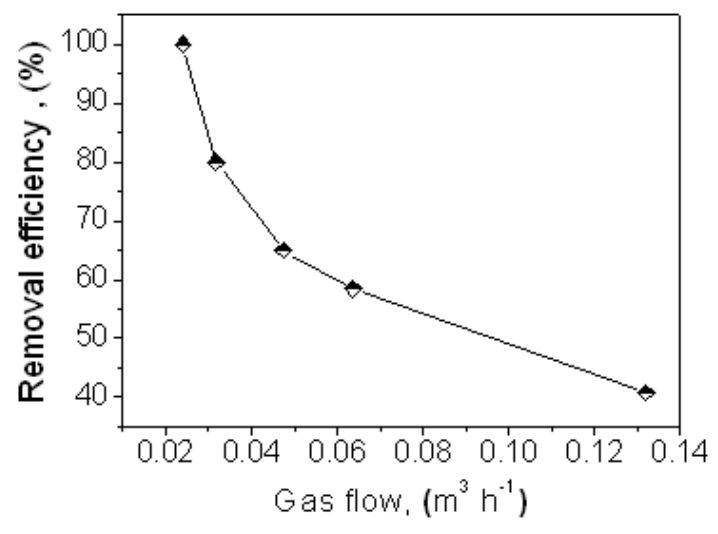

Figure 5. Variation of removal efficiency with different work flows.

between phases, due to the lesser concentration of rising elements between gas and the liquid phase.

Figure 4, shows the suspended biomass and EC variation in the airlift bioreactor. In Figure 4 is possible observe that an increases in the suspended biomass concentration in the reactor, produced a increases in the EC too. This is explained by observing that a greater use of the carbon source favours the mass transfer in the medium which also increases the toluene solubility (according to the aforementioned) in the medium (produced by changes in the liquid phase generated by microbial growth).

The study conducted by Khandan (1999), in an airlift bioreactor used to eliminate toluene, was done with suspended cellular concentrations averaging $2500 \mathrm{~g} \mathrm{~m}^{-3}$ to $100 \mathrm{~g} \mathrm{~m}^{-3} \mathrm{~h}^{-1}$. The average EC was obtained in stationary state conditions. Approximately half of the EC obtained from this work (203 $\mathrm{g} \mathrm{m}^{-3} \mathrm{~h}^{-1}$ ) had an average cellular concentration of $3700 \mathrm{~g} \mathrm{~m}^{-3}$. On the other hand, when a maximum cellular concentration of $8000 \mathrm{~g} \mathrm{~m}^{-3}$ was utilized, a $310 \mathrm{~g} \mathrm{~m}^{-3} \mathrm{~h}^{-1}$ EC was obtained. Although this biomass concentration was observed for only 3 days in operation it is appropriate to indicate that an increase in concentration of suspended biomass, of approximately double the average, an increase of approximately 53\% in the EC occurs. These results reflect the clear dependence of the EC with the biomass concentration in the reactor, suggesting that an increase of biomass quantity in the reactor will allow for greater EC. However, as shown in Figure 4, although during the first three days of operation there is a greater concentration of biomass $\left(\sim 230 \mathrm{~g} \mathrm{~m}^{-3}\right)$, the EC is lower $\left(\sim 170 \mathrm{~g} \mathrm{~m}^{-3} \mathrm{~h}^{-1}\right)$ than between four to six days of operation, in which there is a lower concentration of biomass suspended. This may be due to the lower toluene inlet load into the reactor during those days of operation.

The study on the management of high cellular concentrations in an airlift bioreactor for the elimination of VOC's has been done so by Oliveira and de França (2005) who worked with cellular concentrations of $2000 \mathrm{~g} \mathrm{~m}^{-3}$ obtaining a hexane RE of around $90 \%$.

\section{Effect of gas flow on removal efficiency}

Figure 5 shows the RE variation in the bioreactor with an increase in flow operation. Here, it can be observed that toluene RE decreases as the flow of gas increases. In increasing the operation flow, a decrease in contact time between toluene and the liquid phase exists. The toluene transferred to this phase also decreases. Aside from what was previously mentioned, the toluene concentration introduced is decreased as the flow is increased (given that time of contact in the toluene saturator decreases, distancing itself from the balanced concentration). This also generates a decrease in the gradient concentration of toluene between the gas introduced and the liquid, producing lower transfer of contaminated matter from the gaseous to the liquid phase.

In Figure 5 it can be observed that the system is sensitive to flow variations. The RE drops sharply from $100 \%$ to almost $40 \%$ when the initial flow is increased from $2.4 \times 10^{-2}$ to $0.132 \mathrm{~m}^{3} \mathrm{~h}^{-1}$. This evidence shows the lack of flexibility in these types of reactors when a change in flow occurs. However, this can be solved by increasing the height of the bioreactor column, which will increase residence time between both phases and/or increase biomass concentration in the bioreactor.

\section{Toluene inlet load effect}

Figure 6 and Figure 7 show the effect of the increase of TL and EC and the evolution of the RE, respectively. The study regarding the effect of the TL on the EC took place once a stationary state was reached in the bioreactor.

From Figure 6, it is possible to observe that critical EC $100 \%$ of RE, was obtained for a TL of $174 \mathrm{~g} \mathrm{~m}^{-3} \mathrm{~h}^{-1}$ (critical

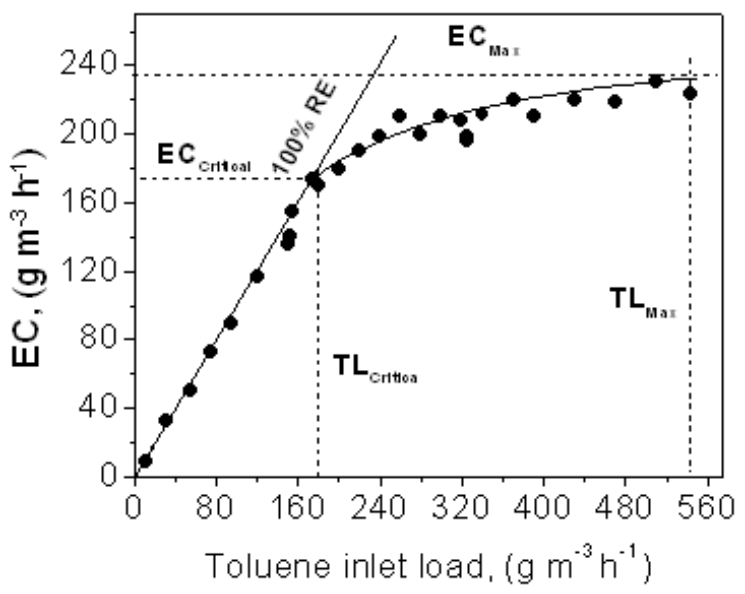

Figure 6. Effect of toluene inlet load regarding elimination capacity of the airlift bioreactor. 


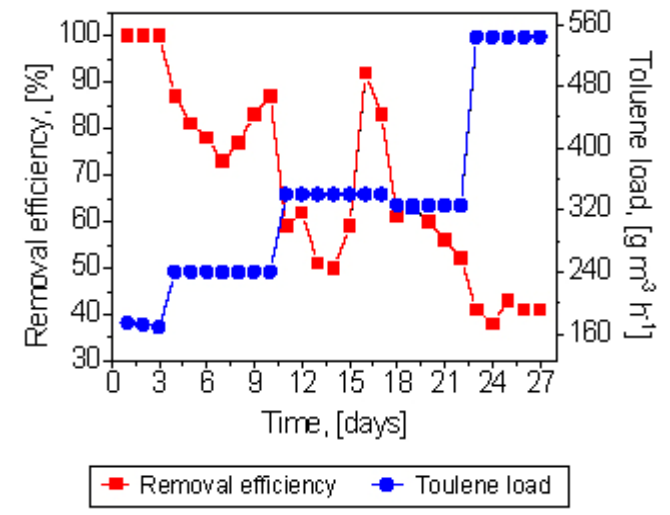

Figure 7. Variation of removal efficiency for different toluene inlet loads in the airlift bioreactor.

TL). On the other hand, Figure 7 demonstrates that RE decreases sharply to $40 \%$ for a TL over critical TL. However, the EC increase is associated with the work flow variation and not with the increased toluene elimination.

On increasing TL the EC increases reaching a maximum EC of $230 \mathrm{~g} \mathrm{~m}^{-3} \mathrm{~h}^{-1}$ for a maximum TL of $550 \mathrm{~g} \mathrm{~m}^{-3} \mathrm{~h}^{-1}$. It can be observed from Figure 6 that for operation loads between 174 and $500 \mathrm{~g} \mathrm{~m}^{-3} \mathrm{~h}^{-1}$, the system finds itself limited by the transfer, while for loads of $500 \mathrm{~g} \mathrm{~m}^{-3} \mathrm{~h}^{-1}$, the limiting factor of the system is a biological reaction, reaching the maximum EC of the reactor.

The maximum EC result $\left(230 \mathrm{~g} \mathrm{~m}^{-3} \mathrm{~h}^{-1}\right)$ obtained in this work was similar to the $250 \mathrm{~g} \mathrm{~m}^{-3} \mathrm{~h}^{-1}$ attained by Woertz et al. (2001) utilizing the yeast Exphilia lecanii-corni as a biological agent. This maximum EC equivalent was also similar to the $240 \mathrm{~g} \mathrm{~m}^{-3} \mathrm{~h}^{-1}$ obtained by Aizpuru et al. (2005) and $40 \%$ less than what was obtained by GarcíaPeña et al. (2001), both utilizing fungi biofilters normally used for the elimination of hydrophobic VOC'S. On the other hand, the maximum EC obtained was 2 times greater than what was obtained by Hwang and Tang (1997) and Gabaldón et al. (2006) utilizing bacterial biofilters for the toluene elimination. From these results, it is possible to observe that airlift bioreactors possess RE and VOC'S similar to those obtained with steady-bed fungi biofilters, which indicates that it is feasible to reduce some transport limitations which appear in bacterial biofilters on utilizing airlift bioreactors. It must be taken into account that in the case of fungi biofilters this increase in EC is produced by an increase in the transport area generated by miceliar growth and the hydrophobic properties of fungus (VergaraFernández et al. 2006).

\section{CONCLUDING REMARKS}

The airlift bioreactor is an alternative solution for the elimination of contaminants present in gaseous effluents (toluene vapours) that work at shorter residence periods than a biofilter inoculated with bacteria.

It is possible to obtain EC in the range of 150 to $230 \mathrm{~g} \mathrm{~m}^{-3}$ $\mathrm{h}^{-1}$ in an airlift bioreactor, maintaining cellular concentrations between 3000 and $5000 \mathrm{~g} \mathrm{~m}^{-3}$ for toluene concentrations lesser to $14 \mathrm{~g} \mathrm{~m}^{-3}$.

The airlift bioreactor has operational advantages in toluene biodegradation, compared to systems of fixed-bed, given that the absence of canalizations and the non existence of zones died in the bioreactor.

The toluene RE decrease from $100 \%$ to $40 \%$ when the gas flow increased to $2.4 \times 10^{-2}$ to $0.132 \mathrm{~m}^{3} \mathrm{~h}^{-1}$. A decrease in residence time of gas in the reactor affects the transport mass of the toluene from the gas to the liquid phase.

The airlift bioreactor shows a disadvantage due to the lack of flexibility in great changes of gas flow, which is reflected in a drastic diminution of the RE. Nevertheless, this situation can be solved by controlling the biomass concentration in the bioreactor. In accordance to increased operations or by constructing the reactor by means of modules that can be added or be eliminated according to the residence time that is necessary to obtain.

\section{ACKNOWLEDGMENTS}

The authors wish to thank the Dirección de Investigación de la Universidad Católica de Temuco for financing this research (Project DIUCT 2002-4-01).

\section{REFERENCES}

AIZPURU, Aitor; DUNAT, Bertrand; CHRISTEN, Pierre; AURIA, Richard; GARCÍA-PEÑA, Inés and REVAH, Sergio. Fungal biofiltration of toluene on ceremic rings. Journal Environmental Engineering, March 2005, vol. 131, no. 3, p. 396-402.

AROCA, G.; URRUTIA, H.; NÚÑEZ, D.; OYARZÚN, P.; ARANCIBIA, A. and GUERRERO, K. Comparison on the removal of hydrogen sulfide in biotrickling filters inoculated with Thiobacillus thioparus and Acidithiobacillus thiooxidans. Electronic Journal of Biotechnology, October, 2007, vol. 10, no. 4, p. 514-520.

DAVISON, Brian; BARTON, John; KLASSON, Thomas and FRANCISCO, Alex. Influence of high biomass concentrations on alkane solubilities. Biotechnology Bioengineering, May 2000, vol. 68, no. 3, p. 279-284.

DELHOMENIE, M.C.; BIBEAU, L.; GENDRON, J.; BRZEZINSKI, R. and HEITZ, M. Degradation of toluene, xylene, and trimethylbenzene vapors by biofiltration: a comparison. Journal Air \& Waste Management Association, February 2003, vol. 53, no. 2, p. 217-226. 
GARCÍA-PEÑA, Inés; HERNÁNDEZ, Sergio; FAVELATORRES, Ernesto; AURIA, Richard and REVAH, Sergio. Toluene biofiltration by the fungus Scedosporium apiospermun TB1. Biotechnology Bioengineering, May 2001, vol. 76, no. 1, p. 61-69.

GABALDÓN, Carmen; MARTÍNEZ-SORIA, Vicente; MARTIN, Miguel; MARZAL, Paula; PENYA-ROJA, Josep-Manuel and ALVAREZ-HORNOS, F. Javier. Removal of TEX vapours from air in a peat biofilter: influence of inlet concentration and inlet load. Journal of Chemical Technology and Biotechnology, 2006, vol. 81, no. 3, p. 322-328.

HWANG, Shyh-Jye and TANG, Hsiu-Mu. Kinetic behavior of the toluene biofiltration process. Journal Air \& Waste Management Association, June 1997, vol. 47, no. 6, p. 664-673.

KHANDAN, N. Prototype development of a novel bioreactor configuration for treating airstreams contaminated with organic vapors. Technical Completion Report, 1999 [cited November 2002]. Portable Document Format. Available from Internet: http://www.werc.net/research/research_reports.htm.

KHANDAN, N. Prototype development of a novel bioreactor configuration for treating VOC contaminated air streams. Technical Completion Report, 1997 [cited November 2002]. Portable Document Format. Available from Internet: http://www.werc.net/research/research_reports.htm.

LO, C. and HWANG, S. Degradation of waste gas containing toluene in an airlift bioreactor. Environmental Science Technology, April 2004, vol. 38, no. 7, p. 22712280.

MALHAUTIER, L.; KHAMMAR, N.; BAYLE, S. and FANLO, J.L. Biofiltration of volatile organic compounds. Applied Microbiology Biotechnology, April 2005, vol. 68, no. 1, p. 16-22.

OLIVEIRA, Fernando J.S. and DE FRANÇA Francisca P. Performance of an Internal-Loop Airlift Bioreactor for Treatment of Hexane-Contaminated Air. Applied Biochemistry and Biotechnology, vol. 122, no. 1-3, p. 581591.

TIJHUIS, L.; HUSMAN, L.; HEKELMAN, H.; VAN LOOSDRECHT, M. and HEIJNEN, J. Formation of nitrifying biofilms on small suspended particles in airlift reactors. Biotechnology Bioengineering, September 1995, vol. 47, no. 5, p. 585-595.

VERGARA-FERNÁNDEZ Alberto; LARA Lucia; ALARCÓN, Nelson and AROCA, Germán. Effects of gas flow rate, inlet concentration and temperature on the biofiltration of toluene vapors. Journal of Environmental Management, July 2007, vol. 84, no. 2, p. 115-122.
VERGARA-FERNÁNDEZ, Alberto; VAN HAAREN, Brice and REVAH, Sergio. Phase partition of gaseous hexane and surface hydrophobicity of Fusarium solani when grown in liquid and solid media with hexanol and hexane. Biotechnology Letters, December 2006, vol. 28, no. 24, p. 2011-2017.

WOERTZ, J.R.; KINNEY, K.A.; MCINTOSH, N.D. and SZANISZLO, P.J. Removal of toluene in a vapor-phase bioreactor containing a strain of the dimorphic black yeast Exophiala lecanii-corni. Biotechnology Bioengineering, December 2001, vol. 75, no. 5, p. 550-558.

WUBKER, S.; LAURENZIS, A.; WERNER, U. and FRIEDRICH, C. Controlled biomass formation and kinetics of toluene degradation in a bioscrubber and in a reactor with a periodically moved trickle-bed, Biotechnology Bioengineering, August 1997, vol. 55, no. 4, p. 686-693.

YU, H.; KIM, B.J. and RITTMANN, B.E. Contributions of biofilm versus suspended bacteria in an aerobic circulatingbed biofilm reactor. Water Science Technology, 2001, vol. 43, no. 1, p. 303-310.

ZUBER, Laurent; IRVING, Dunn and DESHUSSES, Marc. Comparative scale-up and cost estimation of a biological trickling filter and a three-phase airlift bioreactor for the removal of methylene chloride from polluted air. Journal Air Waste Management Association, September 1997, vol. 47, p. 969-975. 